\title{
The East Syriac Psalm Headings in Manuscript 18>8dt1: Manchester, John Rylands Library, Rylands Syriac Manuscript $\mathbf{4}^{1}$
}

\author{
HeRrie VAN ROOY (NORTh-WeSt UNIVERSITY) ${ }^{2}$
}

\begin{abstract}
Manuscript 18>8dt1 dates from AD 1727 and was copied from an earlier Eastern manuscript, now lost. The oldest manuscript that contains the East Syriac headings is 6t1, a Western manuscript with Western orthography. The oldest Eastern manuscripts that contain these headings date from the twelfth century. The John Rylands manuscript contains the headings in a form 400 years older than the oldest of the other Eastern manuscripts, giving new insight into the history of these headings. The value of this manuscript can be judged when its headings are compared to those in $6 t 1$ and 12t4. Many headings have shorter and longer versions. This paper explores the place of $18>8 d t 1$ in the history of the East Syriac Psalm headings to demonstrate the originality of many of the readings in this manuscript. The conclusion is the headings in $6 t 1$ cannot always be regarded as reflecting the original headings.
\end{abstract}

KEYWORDS: Syriac psalms; Peshitta; John Rylands library; psalms headings/superscriptions; $18^{\text {th }}$ Century AD manuscript.

\section{A INTRODUCTION}

Manuscript 18>8dt1 dates from AD 1727 and was copied from an earlier Eastern manuscript, now lost. It was given the number $18<13 \mathrm{dt} 1$ in the original list of manuscripts published by the Peshitta Institute in Leiden. That has now been changed to $18<8 \mathrm{dt} 1$, which means the original manuscript copied was from the $8^{\text {th }}$ century, and not the $13^{\text {th }}$ century, as had been thought earlier. The oldest manuscript that contains these headings is $6 \mathrm{t} 1$, a Western manuscript with Western orthography. The oldest Eastern manuscripts containing these headings date from the $12^{\text {th }}$ century. The John Rylands manuscript contains the headings in a form 400 years older than the oldest of the other Eastern manuscripts, giving new insight into the history of these headings. The value of this manuscript can

* Article submitted: 2019/03/04; peer reviewed: 2019/05/17; accepted: 2019/07/16. Herrie van Rooy, "The East Syriac Psalm Headings in Manuscript 18>8dt1: Manchester, John Rylands Library, Rylands Syriac Manuscript 4," OTE 32 no. 2 (2019): 716-728. DOI: https://doi.org/10.17159/2312-3621/2019/v32n2a22.

1 I dedicate this paper to our colleague and friend Phil Botha upon his $65^{\text {th }}$ birthday.

2 This work is based on the research supported by the National Research Foundation. Any opinion, finding and conclusion or recommendation expressed in this material is that of the author and the NRF does not accept any liability in this regard. 
be judged when its headings are compared to those in $6 \mathrm{t} 1$ and $12 \mathrm{t} 4$. Many headings have shorter and longer versions. In some instances, 18>8dt1 agrees with $12 \mathrm{t} 4$ and $6 \mathrm{t} 1$ in having a longer heading, as in Pss 2 and 9. Sometimes, 6t1 has a longer reading, while 12t4 and 18>8dt1 have shorter readings (Pss 11 and 42). This paper will explore the place of $18>8 \mathrm{dt} 1$ in the history of the East Syriac Psalm headings with a view to demonstrate the originality of many of the readings contained in this manuscript.

\section{B THREE IMPORTANT MANUSCRIPTS WITH THE EAST SYRIAC HEADINGS}

The manuscripts to which this contribution refers are among those for which the Peshitta Institute in Leiden developed a siglum to identify them for the publication of a critical edition of the Peshitta. ${ }^{3}$ Each siglum consists of three parts. The number at the beginning refers to the century to which the manuscript is dated, the following letter indicates the kind of manuscript and the number at the end distinguishes the different manuscripts of the specific group from the specific century. The siglum for the codex ambrosianus was used to indicate the basic format of the siglum for most of the books in the edition. It is 7a1, which means the first manuscript from the $7^{\text {th }}$ century containing the whole Bible. The siglum $6 \mathrm{t} 1$ indicates the first manuscript of the Psalms from the $6^{\text {th }}$ century, which is the oldest manuscript that contains the East Syriac headings.

The headings of the Psalms in the Hebrew Bible were not retained in the manuscripts of the Peshitta. Some Syriac Psalm manuscripts have no headings for the Psalms. Bloemendaal distinguishes four groups of manuscripts as far as headings are concerned. The groups are manuscripts with the East Syriac headings, manuscripts with the West Syrian tradition (as in 7a), the headings in editions such as the edition of Lee, and manuscripts with a mixture of headings. ${ }^{4}$ The East Syriac headings are related to the great commentary of Theodore of Mopsuestia on the Psalms, as Baethgen already stated in $1885 .^{5}$

In a critical edition of the East Syriac Psalm headings, 17 different manuscripts were used, as well as three printed editions from the $19^{\text {th }}$ century that contain these headings. ${ }^{6}$ For this contribution, three manuscripts are of

3 See Peshitta Institute, List of Old Testament Peshitta Manuscripts (Preliminary issue; Leiden: Brill, 1961). A list of the manuscripts referred to is included before the Bibliography.

4 Willem Bloemendaal, The Headings of the Psalms in the East Syrian Church (Leiden: Brill, 1960), 2-3.

5 Friedrich Baethgen "Der Psalmencommentar des Theodorus von Mopsuestia in syrischer Bearbeitung," ZAW 5 (1885): 53.

6 For a discussion of the manuscripts and editions, see Herculaas F. van Rooy, The East Syriac Psalm Headings: A Critical Edition, Texts and Studies: Third Series 8. (Piscataway, N.J.: Gorgias Press), 2013, 53-66. 
special importance, namely $18<8 \mathrm{dt} 1,6 \mathrm{t} 1$ and $12 \mathrm{t} 4$. They will be discussed briefly.

\section{Manuscript 18<8dt1: Manchester, John Rylands Library, Rylands Syriac Manuscript 4}

This manuscript dates to AD 1727 and was copied in China from an earlier manuscript, now lost. ${ }^{7}$ Originally, the earlier manuscript was dated to the $13^{\text {th }}$ century, but later it was realised that the original manuscript dated from the $8^{\text {th }}$ century, thus the siglum $18<8 \mathrm{dt} 1 .^{8}$

A complete description of this manuscript is given by Coakley. ${ }^{9}$ The first published information about the manuscript dates to 1831 in a note on Syriac manuscripts by S. de Sacy, who said he obtained the manuscript from the heirs of "M. l'abbé Brottier." 10 The manuscript is a facsimile made in China. Mingana also refers to this manuscript. He has read the colophon of the manuscript and says it states the original manuscript dates to the year 1064 of the Greeks (that is AD 752/3), and 134 of the Hijrah, in the time of Cyprian, the metropolitan of Nisibis. ${ }^{11}$ Coakley states the titles are those of the East Syrian tradition and that in some cases white space have replaced them entirely or in part. This means the headings or part of them had already been unclear to the Chinese copyist. ${ }^{12}$ The original manuscript, copied in China, is older than the oldest Eastern manuscript that contains the headings of the Eastern tradition. The China copy of the original manuscript was read on microfilm at the Peshitta Institute in Leiden and the original China copy at the John Rylands Library as well.

\section{$2 \quad$ Manuscript 6t1: London, British Library, Add. Manuscript 17,110}

This manuscript dates from AD 600 or earlier. It had previously been given the number $7 \mathrm{t} 1$ in the list of the Peshitta Institute, but that was changed to $6 \mathrm{t} 1 .{ }^{13}$ Wright published the first complete description of this manuscript. ${ }^{14}$ He notes

\footnotetext{
7 Peshitta Institute, List, 27.

8 James F. Coakley, "A Catalogue of the Syriac Manuscripts in the John Rylands Library," BJRL 75 (1993): 105-207 (122, note 39).

9 Coakley, “A Catalogue of the Syriac Manuscripts," 120-123.

10 A. I. Sylvestre De Sacy, "Notice d'un manuscrit syriaque écrit à la Chine, contenant une portion de la version Syriaque de l'Ancien Testament, des Cantiques, e diverses priéres," Notices et extraits des manuscrits de la Bibliothèque du Roi XII (Paris: Imprimerie Royale, 1831): 277.

11 Alphonse Mingana, "The Early Spread of Christianity in Central Asia and the Far East: A New Document," BJRL 9 (1925): 337.

12 Coakley, "A Catalogue of the Syriac Manuscripts," 121.

13 Donald M. Walter, The Book of Psalms (The Old Testament in Syriac II 3; Leiden: Brill, 1980), VIII.

14 William Wright, Catalogue of Syriac MSS in the British Museum, acquired after the year 1838 I (London: British Museum, 1870), 116-119.
} 
that the headings differ from those in the edition of Lee, as well as from those in additional manuscripts $14,436^{15}$ and $17,109^{16}$. The orthography of the manuscript is Western, while the headings are from the Eastern tradition. ${ }^{17}$

\section{$3 \quad$ Manuscript 12t4: Baghdad, Library of the Chaldean Patriarchate, Manuscript 1113, folios $\mathbf{1 1}^{\mathrm{a}}-\mathbf{1 1 8}^{\mathrm{b}}$ (formerly Mossoul, Library of the Chaldean Patriarchate, Manuscript 1113)}

Manuscript $12 \mathrm{t} 4$ dates from the $12^{\text {th }}$ century. It is the most important Eastern text used for the critical edition of the Psalms. ${ }^{18}$ It has four headings for each Psalm. Three are linked to Eusebius, Athanasius and Theodore, while there are headings labelled "Hebrew". 19

\section{THE HEADINGS IN THE RYLANDS MANUSCRIPT}

Before discussing some headings in detail, the general view of variants in the East Syriac headings is briefly explained. In Peshitta manuscripts, the headings of the Hebrew text were not retained but replaced by different headings. In the East Syriac tradition, the headings are related to the interpretation of the psalms by Theodore of Mopsuestia. The heading, which usually gives a historical setting for a specific psalm, can be regarded as a short summary of Theodore's hypothesis at the beginning of his interpretation of a psalm. He did his interpretation in the light of the hypothesis.

The general view of these Syriac headings is offered by Vosté ${ }^{20}$ followed by Bloemendaal, ${ }^{21}$ namely that the East Syriac headings did not change much over the centuries, with the most important change the abbreviation of some headings in more recent manuscripts. A detailed study of the headings in $18>8 \mathrm{dt} 1$ and $12 \mathrm{t} 4$ presents a different picture. To illustrate this finding, a few examples will be discussed first. Not all variants in all the manuscripts will receive attention. The focus will be on the main trends that can be distinguished with reference to the three oldest manuscripts containing the Eastern headings, namely $6 \mathrm{t} 1,18>8 \mathrm{dt} 1$ and $12 \mathrm{t} 4$. The most important readings of the headings will

15 This manuscript contains both $9 \mathrm{t} 2$ and $10 \mathrm{t} 3$.

$169 \mathrm{t} 3$.

17 Bloemendaal, Headings, 13. This is the manuscript Bloemendaal used for his diplomatic edition of the headings.

18 Walter, Psalms, XXVII.

19 This manuscript was discussed in detail before; see Herculaas F. van Rooy, "The 'Hebrew, Psalm headings in the Syriac manuscript 12t4," Journal of Northwest Semitic Languages 25 (1999): 225-237, and Herculaas F. van Rooy, Studies on the Syriac Apocryphal Psalms (Journal of Semitic Studies Supplement 7; Oxford: Oxford University Press, 1999).

20 Jacques-Marie Vosté, "Sur les titres des psaumes dans le Pešitta, surtout d'aprés la recension orientale," Bib. 25 (1944): 210-235.

21 Bloemendaal, Headings, 20-21. 
be given in Syriac with an English translation, but where the exact reading of the Syriac does not make a substantial contribution to the discussion, only a translation will be supplied. All the examples will begin with the reading of the specific heading in the Rylands manuscript.

The first example is Psalm 115, which has a double heading referring to Hezekiah and the exiles in Babylon. In this instance, the longer heading was the original, with different summaries or omissions in different manuscripts.

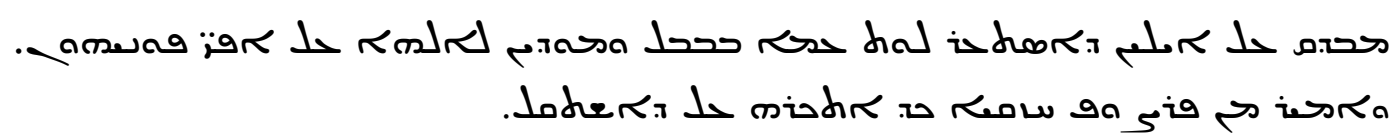

He points out the things that were done to the people in Babel and they praised God about their return. And spoken in the person of Hezekiah when he was sick about what had been taken away.

There are only a few minor differences between this heading and the headings in 6t1 and 12t4. Both add the relative particle before "in Babel".

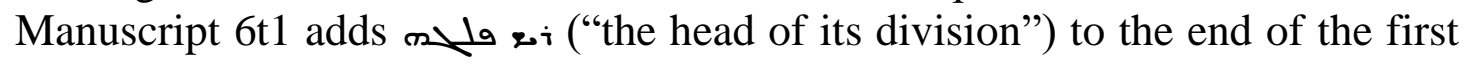
part of the heading and omits the "and" before "spoken".

This is one of the few headings of the Psalms that have a double heading. Some of the later manuscripts (6t2, 17t1, M507) have only the first part of the heading ("He points out the things that were done to the people in Babel and they praised God about their return. The printed Peshitta and Psalter of Urmia have both parts, but in shortened form ("He points out the calamities that the people had endured in Babel and also speaks about Hezekiah, who became ill about what had been taken away"). Something similar occurs in 17t3. Manuscript 13t3 has a shortened version of the first part of the heading ("He points out the calamities that the people in Babel had to endure"). Manuscript M428 has a shortened version of the second part of the heading ("Spoken about Hezekiah, when he became ill about what had been taken away").

This is an interesting example as most of the headings give just one setting for a psalm. The fact that the double heading appears in the oldest manuscripts pleads for its originality and it fits the idea of abbreviation as proposed by Vosté.

Psalm 9 is the second example where the major variant is of the kind discussed by Vosté and Bloemendaal. A longer heading occurs in the majority of the manuscripts (with minor variants):

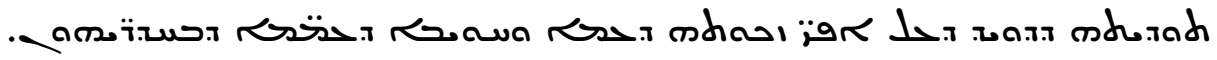

Thanksgiving of David for the victory of the people and the condemnation of the nations surrounding them. 
A shorter heading occurs in M428 and the edition from Mosul. The second part of the heading ("Thanksgiving of David for the victory of the people") is omitted, but the first part of the original heading is retained. The longer form is retained in the three important manuscripts, but also in more recent manuscripts and the edition and Psalter from Urmia.

Psalm 11 is an interesting example with regard to the three important manuscripts. 18>8dt 1 and $12 \mathrm{t} 4$ have the same heading, while $6 \mathrm{t} 1$ has a slightly shorter version of the heading. Manuscript 6tl reads:

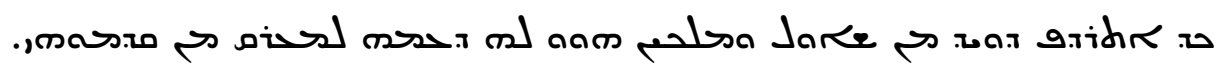

When David was pursued by Saul and those who were with him counselled him to flee before him.

$18>8 \mathrm{dt} 1$ and $12 \mathrm{t} 4$ have the following:

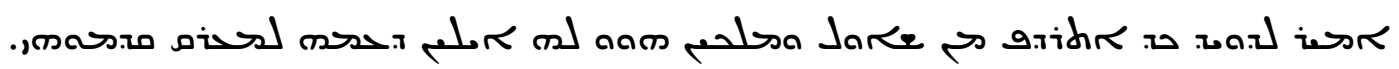

Spoken by David when he was pursued by Saul and those who were with him counselled him to flee before him.

$6 \mathrm{t} 1$ has a shorter version of the heading without "spoken by David". It is more probable to accept the addition of this general introduction than to accept its omission. Thus, it has to be accepted that this heading was expanded by the addition of the introduction in the later manuscripts.

In the next section, some important examples will be discussed where the headings of $18>8 \mathrm{dt} 1$ are important to help determine the original heading.

In many instances, $18>8 \mathrm{dt} 1$ has a reading longer than some of the more recent manuscripts, especially 13t3, M428 and M. In most of these instances, the longer reading is supported by $6 \mathrm{t} 1 \mathrm{and} /$ or $12 \mathrm{t} 4$. Examples of this kind occur in many psalms, such as Pss $9 ; 15 ; 16 ; 18 ; 23 ; 24 ; 29 ; 30 ; 32 ; 33$ and many more. Ps 9 is a typical example. The difference between the two headings is very typical of this kind of variant, where the longer heading consists of more than one phrase and only the first phrase is retained in the shorter heading. The longer heading is:

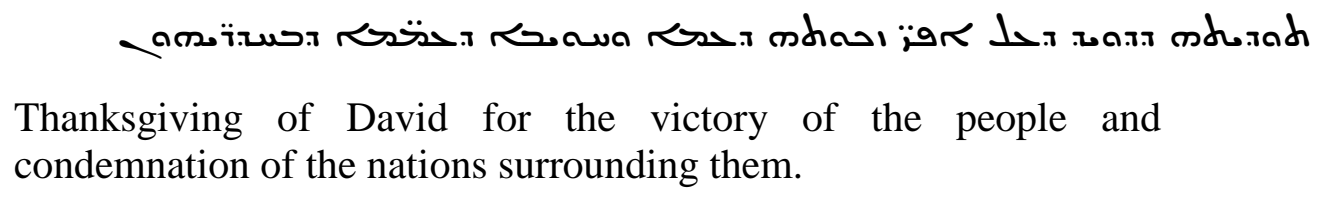

M428 and M omit the second part.

Such variants lead Vosté, followed by Bloemendaal, to conclude the main variants in the East Syriac headings are shortened versions of the original 
heading. This kind of variant occurs frequently, but is not the only type of variant. There are about 30 psalms where the headings remained fairly consistent in all the manuscripts. In the instances where shorter headings are found, they are restricted to a number of manuscripts in most instances. There are 44 instances where the shorter heading occurs in 13t3 and M428; in some instances, one or a few other manuscripts have shorter headings as well. In 31 instances, the shorter heading occurs in $13 \mathrm{t} 3$, along with some other manuscripts in some instances, except M428. In 25 instances, shorter headings occur in M428 and some other manuscripts, but not in 13t3. Although these shorter headings are important, the fact that they are restricted to just a small number of manuscripts makes them less important than some of the other possibilities discussed below.

There are a few headings where $6 \mathrm{t} 1$ has a longer reading than the majority of manuscripts, while $18>8 \mathrm{dt} 1$ and $12 \mathrm{t} 4$ support the shorter reading. For Psalm 10, only 6t1 and 13t1 have ruds at the beginning of the heading. In Ps 61, 6t1

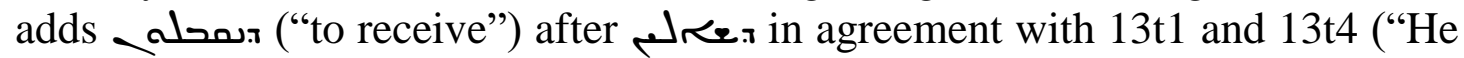
relates the things done to the people in Babel and how they asked for help").

Psalm 104 is a very interesting example. 6t 1 has a slightly longer reading (with amongst others $16 \mathrm{t} 2$ and $17 \mathrm{t} 1$ ), than the majority of manuscripts while $18>8 \mathrm{dt} 1$ and $12 \mathrm{t} 4$ (with 13t1, 13t2, 13t4, 17t2, 17t3, M25, M507 U, U⿱口 and M) do not have the reference to "help".

6t1reads as follows:

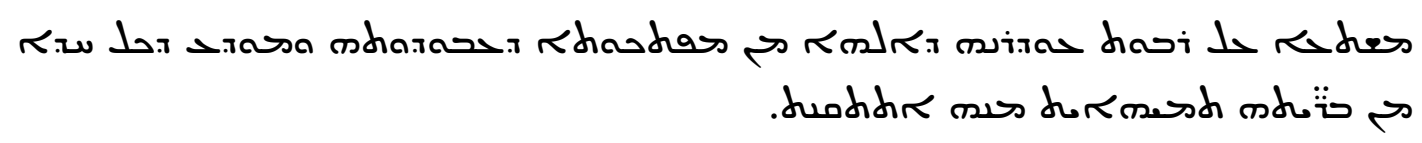

He narrates about the greatness of the help of God in the variety of his (creative) activity and says that God formed every one of his creatures admirably.

In these instances, where the shorter heading is found in $12 \mathrm{t} 4$ and $18>8 \mathrm{dt} 1$, the shorter heading cannot be regarded as a late variant, but must be evaluated in its own right. In these instances, the shorter heading may be closer to the original than the heading of $6 \mathrm{t} 1$.

In some instances, most of the manuscripts, including $18>8 \mathrm{dt} 1$ and $12 \mathrm{t} 4$, have a longer reading than $6 \mathrm{t} 1$; however, $6 \mathrm{t} 1$ has the same information as the other manuscripts, although it is constructed in a different way. Ps 11 is a good example. $18>8 \mathrm{dt} 1$ and $12 \mathrm{t} 4$ have the following heading:

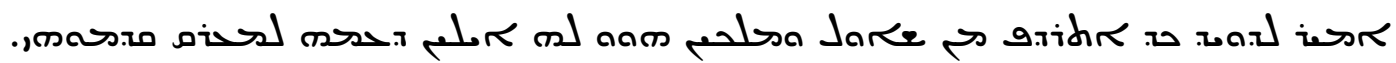

Spoken by David when he was pursued by Saul and those who were with him counselled him to flee before him. 
$6 \mathrm{t} 1$ has the same information:

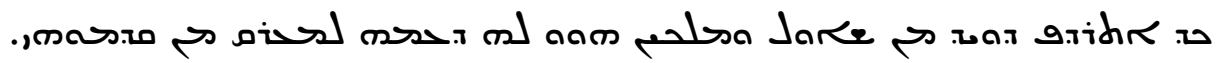

When David was pursued by Saul and those who were with him counselled him to flee before him.

In this instance, $6 \mathrm{t} 1$ does not have the introduction linking the psalm to David ("Spoken by David"). This makes it necessary to add the name of David after the verb ("was pursued"). The fact that the two other important manuscripts and the majority of the other manuscripts have the introduction creates the possibility that they contain the original heading.

Psalm 42 is a similar example. $6 \mathrm{t} 1$ has a construction different from the other manuscripts, for example $18>8 \mathrm{dt} 1$ and $12 \mathrm{t} 4$, but they all have the same

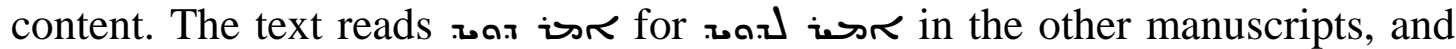
("Spoken by David, in the person of the people in Babel, telling them what words to use in the time of their exile"). In these instances, it should not be accepted that the heading of $6 \mathrm{t} 1$ is necessarily closer to the original, but rather the heading supported by the other two important manuscripts.

A minor difference is found in Ps 20 when $6 \mathrm{t} 1$ is compared to the other manuscripts. All the headings connect the Psalm to Hezekiah and the Assyrians. 6t 1 refers to the time when Hezekiah was delivered from the Assyrians, while the others refer to the time when he was oppressed by the Assyrians. No remark on this palm by Theodore has been preserved. Diodore links both Pss 20 and 21 to Hezekiah and the Assyrians: Ps 20 to the time before Hezekiah and the deliverance of Jerusalem from the Assyrians, and Ps 21 to the joy after the deliverance. ${ }^{22}$ This could make it possible that $6 \mathrm{t} 1$ preserves the older version of the headings. In Ps 20, however, 6t1 has the verb , "وfir ("to be delivered"), while the other manuscripts have strir ("to be oppressed"). Again, from the above arguments, a general conclusion cannot be made that $6 \mathrm{t} 1$ has preserved the original reading.

The heading of Ps 41 in 6t1 refers to the sickness (حمim) of Hezekiah. This is the reading of the majority of the witnesses. However, 18>8dt1, 12t1, $12 \mathrm{t} 4$ and M25 refer to his affliction ( he refers to Hezekiah's illness in this psalm, ${ }^{23}$ making it possible that $6 \mathrm{t} 1$ has retained the original heading. Again, this possibility does not warrant a general conclusion.

22 See Robert C. Hill, Diodore of Tarsus: Commentary on Psalms 1-51 (WGRW 9; Atlanta; GA: SBL, 2005), 64-65.

23 See Robert C. Hill, Theodore of Mopsuestia: Commentary on Psalms 1-81 (WGRW 5; Atlanta, GA: SBL, 2006), 506-509. 
Ps 46 is one of the instances where 6t1 has its own version with the following heading:

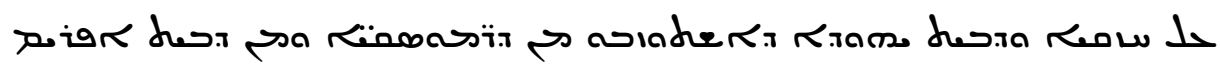

About Hezekiah and those of the house of Judah who were delivered from the Damascenes and from those of the house of Ephraim.

With a few minor variations, the following heading occurs in the majority of the other witnesses, including the two other important Eastern manuscripts:

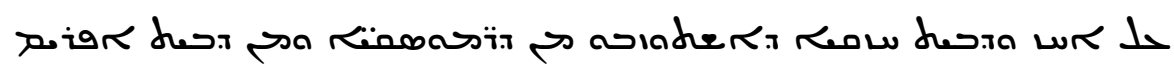

About Ahaz and those of the house of Hezekiah that were delivered from the Damascenes and from those of the house of Ephraim.

In this instance, the introduction of Theodore to this psalm refers to Ahaz and not to Hezekiah at all. In the commentary on this psalm, there is also no reference to Hezekiah. ${ }^{24}$ Here again, the two oldest Eastern witnesses probably have the original heading.

In Ps 82, 6t1, 18>8dt1 and 12t4 (together with some other witnesses) have a much shorter heading than a number of more recent witnesses.

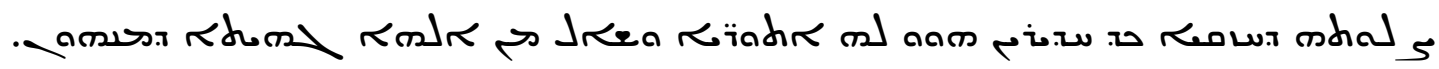

Prayer of Hezekiah when the Assyrians surrounded him and he asked

God to deliver him from them.

The longer heading occurs in M25 and M:

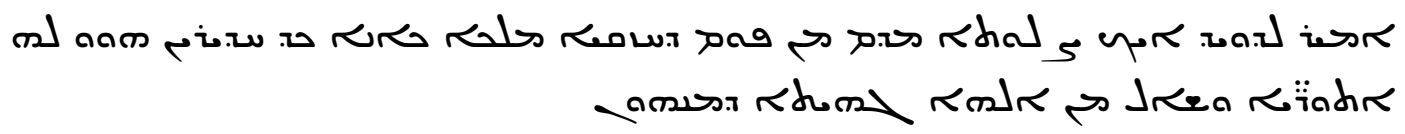

Spoken by David as a sort of prayer from the mouth of Hezekiah, the just king, when the Assyrians surrounded him and he asked God to deliver him from them.

Here the shorter heading is to be regarded as the original, while an expansion occurs in manuscripts that are more recent. This is contrary to the general trend as stated by Vosté and Bloemendaal.

For Ps 126, 6t1 has the following heading:

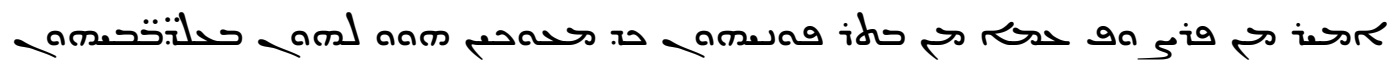

24 See Hill, Theodore, 600-613. 
Spoken in the person of the people after their return when their enemies impeded them.

To the above, 18>8dt1 and 12t4 add (from the building of the temple") (as is done by 13t1, 13t2, 13t3, 13t4, 17t1 and 17t3).

17t2, M25, U, UP,$M$ have a much-expanded heading:

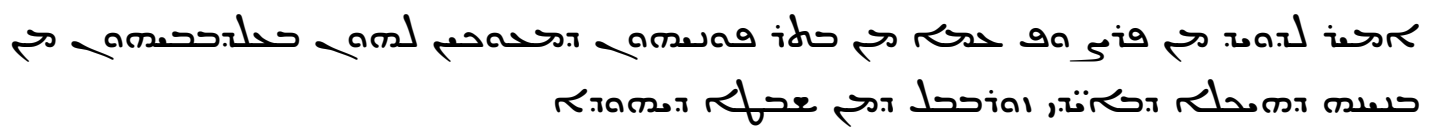

Spoken by David in the person of the people after their return when their enemies prevented them from building the temple by the hands of Zerubbabel from the tribe of Judah.

This is a very important example. The additional phrase that occurs in $12 \mathrm{t} 4,18>8 \mathrm{dt} 1$ and a number of other manuscripts makes perfect sense. The omission in $6 \mathrm{t} 1$ makes the exact context of the heading unclear. In this instance, the shortened heading of $6 \mathrm{t} 1$ must be an early revision of the slightly longer original heading, while $17 \mathrm{t} 2$ and others have a more recent expanded version.

At the end of the heading of Ps 146, 18>8dt1 and 12t4 add حרمזא זכר as is done by $13 \mathrm{t} 1,13 \mathrm{t} 4,16 \mathrm{t} 2,17 \mathrm{t} 1,17 \mathrm{t} 3$ and M25 ("He prophesies about the people in Babel and gives praise in their person for that that was done for them by God").

These examples go against the view of Bloemendaal and Vosté that original longer headings were shortened in later manuscripts. It has to be remembered that many of the headings, for example, those of Pss 22; 25 and 27, were quite short in $6 \mathrm{t} 1$ and all the other witnesses. It may be quite possible that in some instances, $6 \mathrm{t} 1$ has an expanded heading, while the shorter heading may be the original.

It is also clear from the examples discussed that in many instances, 6t1, $8>8 \mathrm{dt} 1$ and $12 \mathrm{t} 4$ have a reading longer than some of the more recent manuscripts, especially 13t3, M428 and M. This kind of heading that leads Vosté to conclude that the main variants in the headings are shortened versions of the original heading. Because these shorter headings occur in only a few of the manuscripts, this phenomenon should not lead to conclusions about a general trend.

There are a number of examples where 6t1 (supported by one or two manuscripts that are more recent) have a slightly longer heading than most of the other manuscripts, as in Pss 10; 16 and 104. The longer headings in these instances have just one word more than the more general heading. This may reflect a change from the original heading in $6 \mathrm{t} 1$, so that $18>8 \mathrm{dt} 1$ and $12 \mathrm{t} 4$ reflect the more original heading. The same is probably true in those instances where 
the heading in $6 \mathrm{t} 1$ has the same information as the other manuscripts but phrased in a slightly different way. Ps 11 is a good example in this regard.

In three instances, $6 \mathrm{t} 1$ has a heading different from the other manuscripts. The headings here have a slightly different setting, as is the case of Ps 20 discussed above. In this instance, $6 \mathrm{t} 1$ has no support from any manuscript. The same is true of the variant in Ps 46. In this instance, the commentary of Theodore has no reference to Hezekiah, as discussed above. In Ps 41, 6t1 has a reading that occurs in other manuscripts as well, but not in $18>8 \mathrm{dt} 1$ and $12 \mathrm{t} 4$. In these instances, 6t1 probably also reflects an early revision of the heading.

In a number of instances, 6t 1 has a shorter heading. Some of these are related to a single word, as in Pss 20 and 41. In Ps 44, it omits the final phrase of the heading (as in M). As the reference to Antiochus, who forced the people, was part of the summary of Theodore ${ }^{25}$ and as the heading makes more sense with the addition, the heading of $6 \mathrm{t} 1$ is probably secondary. See Ps 128 , where $6 \mathrm{t} 1$ omits the last two words. More important are examples such as Ps 82, where 6t1 is substantially shorter. In this instance, the reading of $6 \mathrm{t} 1$ has substantial support, and the shorter heading is probably the original one. The same is true of the headings of Pss 108 and 110.

Psalm 126 is an interesting example, as discussed above. Some more recent witnesses have a much longer heading. A somewhat shorter heading occurs in the majority of manuscripts. 6t 1 has a shortened heading, omitting the phrase "from building the temple". This phrase occurs in 18>8dt1, 12t4 and many other manuscripts. In this instance, $18>8 \mathrm{dt} 1$ and $12 \mathrm{t} 4$ probably have the original heading, while $6 \mathrm{t} 1$ has undergone an early revision and the more recent witnesses a much later revision, as discussed above. The same is true of Ps 146.

As far as other variants in $12 \mathrm{t} 4$ and $18>8 \mathrm{dt} 1$ are concerned, $18>8 \mathrm{dt} 1$ has only one unique reading (Ps 86 ), while $12 \mathrm{t} 4$ has quite a number of variants, sometimes supported by other manuscripts. This testifies to the probability that $18>8 \mathrm{dt} 1$ is much closer to the original than both $6 \mathrm{t} 1$ and $12 \mathrm{t} 4$.

\section{CONCLUSION}

The examples discussed lead to the conclusion that $6 \mathrm{t} 1$ must not be regarded as the paradigmatic witness in all instances. Where $6 \mathrm{t} 1$ is supported by both $12 \mathrm{t} 4$ and $18>8 \mathrm{dt} 1$, the reading can be regarded as at least being close to the original. When $18>8 \mathrm{dt} 1$ supports $6 \mathrm{t} 1$, and $12 \mathrm{t} 4$ has variants, the reading of $6 \mathrm{t} 1$ and $18>8 \mathrm{dt} 1$ can be regarded as closer to the original. When $12 \mathrm{t} 4$ and $18>8 \mathrm{dt} 1$ have a reading different from $6 t 1$, the reading of these two manuscripts is probably closer to the original.

25 Hill, Theodore, 538-539. 


\section{E LIST OF MANUSCRIPTS}

$6 \mathrm{t} 1$ London, British Library, Add. Manuscript 17,110.

18>8dt1 Manchester, John Rylands Library, Rylands Syriac Manuscript 4. 12t1 London, British Library, Add. Manuscript 14,674, I, folios $1^{\mathrm{a}}-78^{\mathrm{b}}$.

12t4 Baghdad, Library of the Chaldean Patriarchate, Manuscript 1113, folios $11^{\mathrm{a}}-118^{\mathrm{b}}$.

13t1 London, British Library, Add. Manuscript 14,675.

$13 \mathrm{t} 2$ London, British Library, Add. Manuscript 14,677.

13 t3 London, British Library. Add. Manuscript 17,219.

$13 \mathrm{t} 4 \quad$ Leiden, Peshitta Institute, Manuscript 5.

$16 \mathrm{t} 2$ Jerusalem, Greek Patriarchate, Syriac Manuscript 27.

17t1 Cambridge, University Library, Manuscript Oo.1.22.

17t2 London, British Library, Add. Manuscript 7156.

17t3 Paris, National Library, Syriac Manuscript 24.

M25 Birmingham, University Library, Mingana Syriac Manuscript 25.

M428 Birmingham, University Library, Mingana Syriac Manuscript 428.

M507 Birmingham, University Library, Mingana Syriac Manuscript 507.

U Old Testament published in Urmia in 1852.

$\mathrm{U}^{\mathrm{P}} \quad$ Psalter published in Urmia in 1891.

M Syriac Bible published in Mosul between 1886 and 1891.

\section{BIBLIOGRAPHY}

Baethgen, Friedrich. "Der Psalmencommentar des Theodorus von Mopsuestia in syrischer Bearbeitung." Zeitschrift für die alttestamentliche Wissenschaft 5 (1885): 53-101. https://doi.org/10.1515/zatw.1885.5.1.53.

Bloemendaal, Willem. The Headings of the Psalms in the East Syrian Church. Leiden: Brill, 1960.

Coakley, James F. "A Catalogue of the Syriac Manuscripts in the John Rylands Library." Bulletin of the John Rylands University Library of Manchester 75 (1993): 105-207. https://doi.org/10.7227/bjrl.75.2.2.

De Sacy, A. I. Sylvestre. "Notice d'un manuscrit syriaque écrit à la Chine, contenant une portion de la version Syriaque de l'Ancien Testament, des Cantiques, e diverses priéres." Notices et extraits des manuscrits de la Bibliothéque du Roi XII (1831): 277-286.

Hill, Robert C. Diodore of Tarsus: Commentary on Psalms 1-51. Writings from the Greco-Roman World 9. Atlanta, GA: Society of Biblical Literature, 2005.

Hill, Robert C. Theodore of Mopsuestia: Commentary on Psalms 1-81. Writings from the Greco-Roman World 5. Atlanta, GA: Society of Biblical Literature, 2006.

Mingana, Alphonse. "The Early Spread of Christianity in Central Asia and the Far East: a New Document." Bulletin of the John Rylands University Library of Manchester 9 (1925): 297-371. https://doi.org/10.7227/bjrl.9.2.2.

Peshitta Institute. List of Old Testament Peshitta Manuscripts (Preliminary issue). Leiden: Brill, 1961. 
728 Van Rooy, "East Syriac Psalm Headings," OTE 32/2 (2019): 716-728

Van Rooy, Herculaas F. The East Syriac Psalm Headings: A Critical Edition, Texts and Studies: Third Series 8. Piscataway, N.J.: Gorgias Press 2013. https://doi.org/ $10.31826 / 9781463234140$.

Van Rooy, Herculaas F. "The 'Hebrew' Psalm headings in the Syriac manuscript 12t4." Journal of Northwest Semitic Languages 25 (1999): 225-237.

Van Rooy, Herculaas. Studies on the Syriac Apocryphal Psalms. Journal of Semitic Studies Supplement 7. Oxford: Oxford University Press, 1999.

Vosté, Jacques-Marie. "Sur les titres des psaumes dans le Pešitta, surtout d'aprés la recension orientale." Biblica 25 (1944): 210-235.

Walter, Donald M. The Book of Psalms. The Old Testament in Syriac II 3. Leiden: Brill, 1980.

Wright, William. Catalogue of Syriac MSS in the British Museum acquired after the year 1838 I. London: British Museum, 1870.

Prof Herrie van Rooy, Professor Emeritus, Faculty of Theology, North-West University, South Africa, Email Herrie.VanRooy@nwu.ac.za. ORCID: https://orcid.org/0000-0001-5032-2356. 